\title{
Dry Port Development in Togo: A Multi-Criteria Approach Using Analytic Network Process [ANP]
}

\author{
Degbe Sewodo Augustin ${ }^{1}$, Dassanou Latre Akossiwa ${ }^{2}$, Degbe Nana Esther ${ }^{3}$ \\ ${ }^{1}$ School of Economics and Management, Shanghai Maritime University, Shanghai, China \\ ${ }^{2}$ College of Transport and Communications, Shanghai Maritime University, Shanghai, China \\ ${ }^{3}$ School of Economics and Management, Shanghai Maritime University, Shanghai, China \\ Email: ‘augustin@stu.shmtu.edu.cn, latre@stu.shmtu.edu.cn, esther@stu.shmtu.edu.cn
}

How to cite this paper: Augustin, D.S., Akossiwa, D.L. and Esther, D.N. (2019) Dry Port Development in Togo: A Multi-Criteria Approach Using Analytic Network Process [ANP]. American Journal of Industrial and Business Management, 9, 1301-1317. https://doi.org/10.4236/ajibm.2019.96086

Received: May 6, 2019

Accepted: June 7, 2019

Published: June 10, 2019

Copyright $\odot 2019$ by author(s) and Scientific Research Publishing Inc. This work is licensed under the Creative Commons Attribution International License (CC BY 4.0).

http://creativecommons.org/licenses/by/4.0/

\section{(c) (i) Open Access}

\begin{abstract}
This paper aims to determine an optimum location for dry port development in Togo. The dry port location decision problem is formulated using Analytic Network Process which consists of multi-criteria evaluation techniques through a pairwise comparison and a super-matrix formation. This research also conducted a field survey through questionnaires and interviews in order to retrieve adequate data from group of experts which were analyzed in establishing the ANP model using Super Decision software. Sokodé has the highest ideal score of 0.94 among other selected alternatives thus, making it the best location for establishing a dry port in Togo. Although all parameters estimated should be uncertain in reality, the sensitivity analysis of the model still indicates that the output results are quite stable. Furthermore, the port of Lomé is also considered as the gateway port providing both inbound and outbound traffic to the hinterland locations within Togo and also to West African landlocked countries.
\end{abstract}

\section{Keywords}

Dry Port, Analytic Network Process (ANP), Togo

\section{Introduction}

Facility location decision making or the expansion of an existing capacity is of great importance to a decision maker faced with such requirements. This is because the cost of construction makes facility location a long term investment decision. Moreover, they are often fixed and difficult to alter in short or intermediate term. The optimum location for every facility should result in higher economic benefits and increase productivity with adequate distribution network, 
thus selecting the best location from a given set of substitutes requires a good assessment of both quantitative and qualitative criteria and sub-criteria. Inadequate facility location often results to excess cost incurred throughout the lifetime of the facilities, no matter how well the production plans, transportations options, inventory management and information sharing decisions are optimized in response to changing conditions.

According to [1], dry port remains an important node in the entire supply chain framework that cannot be ignored both in practice and as an identifiable field of research. Before establishing a dry port, the choice of location is critically assessed as the location has a great impact on its overall performance, especially when considering its intermodal connectivity. Apart from providing services as an intermodal terminal or a consolidation node for other transport modes, dry ports have also completely changed the inland intermodal transport framework from/to seaports with great capacity traffic nodes such as rail rather than only roads [2] [3]. [4] asserted that in order to be productive, dry ports must be able to generate enough volume of traffic. Thus some dry ports are sited either far or close to industrial or production centers. However, most dry ports are usually not well planned, either too far from the optimal sites under government administrative policies or overinvested which results to a huge waste of resources [5]. [6] recommended that the position of a dry port can be appraised according to theoretical, technical and economic potentials. The theoretical potential could be expressed in the capacity of road traffic and the volume of maritime rail containers predicted for a certain year in the future and concerning certain transportation distance. He also ascertained that technical potentials should be evaluated after the examination of infrastructure requirements, while economic potentials should be founded on the "real" costs of infrastructure and external costs. Therefore, finding an optimum location for dry ports to achieve well-known tradeoffs between cost-adding and cost-saving factors remains a vital issue for decision makers.

The objective of this paper is to derive an optimum location for dry port development in Togo which would relieve the port of Lomé and also enhance sustainable transit traffic to other regions in the country and West African landlocked countries. Additionally, this paper is categorically organized into 5 sections for a comprehensive reading. Section 2 provides brief literature on dry port concept and its development in West Africa. Section 3 illustrates the application of Analytic Network Process and its decompositions which were the same methodology used in this study while Section 4 describes the data and present its estimated results regarding the change in sensitivity analysis to various inputs and its implications. Section 5 provides useful conclusions to this study.

\section{Literature Review}

\subsection{Dry Port Concept and Its Development in West Africa}

For an outstanding review on dry port concept and the qualitative principles concerning the range of services offered by dry ports, we humbly refer interested 
readers to [2] [7] [8] [9] [10] and [11]. We intend to provide a brief literature review on dry port development and the quantitative methodology on dry port location selection. In recent years, studies on dry ports have become contemporary issues because of the continuous increase in demand for effective and efficient hinterland transportation and the challenges faced by various stakeholders. [12] asserted that based on its function and location, a dry port can be categorized as close, midrange or distant dry port. [13] also emphasized that dry ports can be categorized as a seaport-based dry port, city-based dry port, or a border dry port. They further explained that a seaport-based dry port often refers to a facility located at the coast with a pivot function of pre-customs clearance. The sustainability of such port solely rely on the consolidation capacity and function of customs clearance as its proximity to the seaport implies that its objective is to restructure the domestic supply chain and shorten lead times (ibid). According to [14], a city-based dry port is often mainly driven by the extensive growth of domestic economy and it is located within a large logistics clusters or export processing zones. Its primary aim is to absorb demand and support local trade thus signing bilateral agreement with seaports to secure external transportation. From a generic perspective, a border dry port is located in a frontier area far from the seaports and with a main function as a transshipment center or customs clearance services. However in Togo, there is currently no active dry port but we understood the latter classification is relatively more practical since the ownership of a dry port is determined regarding its efficiency, size and transport system.

Since 2010, many port stakeholders in West Africa have paid increasing attention to the development of dry ports due to the competitive pressure of corresponding hinterland with neighboring seaports. For example; Ghana Ports and Harbour Authority [GPHA] has taken an initiative of developing the Boankra inland port while Nigerian Port Authority [NPA] has also embarked on extensive dry port development projects in various parts of Nigeria such as Kaduna, Ibadan, Abia and many other states. In 2018, Cote d'Ivoire signed a mutual agreement with China worth $€ 399.4$ million for the establishment of a dry port at the northern region of the country (Ferkessedougou). In Togo, Bolloré Africa Logistics, a major terminal operator within the region has also signed a mutual agreement with the Port of Lomé and the Togolese government to rehabilitate and extend the current railway network from Lomé to a hinterland location and this agreement also includes the establishment of a dry port in Togo. Furthermore, port authorities in Benin and the government of Niger Republic have also signed a bilateral agreement in developing dry ports in Dosso, Gaya and Niamey. Many more projects on dry port development are currently underway in order to enhance port productivity and promote inland transportation network within the sub region.

\subsection{Background Information on Port of Lomé}

Located $06^{\circ} 8^{\prime} \mathrm{N}$ and $01^{\circ} 17^{\prime} \mathrm{E}$ along the Gulf of Guinea, the port of Lomé is the 
only port along the coast that can provide access to West African landlocked countries in one day. The port is Togo's major economic engine and handles more than $80 \%$ of its total seaborne trade. With a depth of 16.60 meters, the port of Lomé is presently the only deep-water port that can accommodate $3^{\text {rd }}$ generation vessels and its total quay length measures 2670 meters. Since the inauguration of the new Lomé Container Terminal [LCT] in 2014, the port has doubled its total traffic capacity from 9.2 to 19.3 million tonnes in 2017 (Figure 1). As part of its mission statement for excellence service and becoming the main gateway to the region, the port of Lomé has embarked on extensive infrastructural development projects and these include; rehabilitation and extension of the Ore dock, providing service roads within the port city, relocation of the fishing harbor from the commercial port, development of a dry port as well as reinstallation of damaged railway lines and establishment of new lines connecting the dry port. At the port of Lomé, the port authority and private firms undertake cargo handling operations. The port authority handles major bulk cargoes and coaster vessels while container handling is undertaken by Societed'Entreprise de Manutention Maritime (SE2M). Conventional cargo operations are performed by Sociétéd'Entreprises de Moyenset de Manutentions Maritimes (SE3M). Principal operators at the port of Lomé include: SDV Togo (Shipping agency and a subsidiary of Bolloré Africa Logistics), Togo Terminal (container terminal operator), SAGA Togo (shipping and transit agency), Lomé Multipurpose Terminal (conventional terminal operator), STCM (Shipping agency), SDV-Damco (forwarding agent), GETMA and MSC (shipping companies) [10].

\section{Methodology}

\subsection{Dry Port Location Decision Making and Analytic Network Process [ANP]}

According to [15], decision making remains the core of all managerial functions and it involves selecting an alternative action towards carrying out an aim/goal. This includes making decisions with enhanced decision-making techniques in addition to the traditionally improved collection of information and implementation.

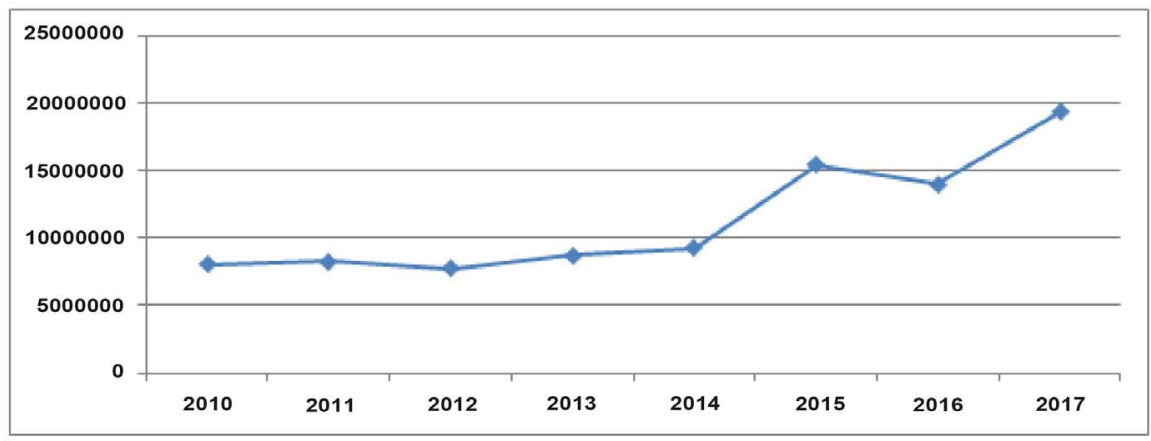

Figure 1. Port of Lomé Global Traffic (2010-2017) million tonnes. Data Sources: Author's compilation from port website:

https://www.togo-port.net/statistiques-pal/trafic-global-port-autonome-lome/ 
Therefore, decision-making is key in order for organizations to gain a competitive advantage. Many organizations spend enormous amounts of time and resources in collecting and analyzing data, however, less effort is spent in assessing alternative decision actions. These forms of decision making is however not adequate for complex and vital decisions. Thus, firms that adopt modern decision support techniques are more strategically positioned to enjoy competitive advantages over their competitors. The two modern decision support techniques that have become very useful to firms recently are the Analytical Hierarchy Process (AHP) and Analytical Network Process (ANP), both developed by Professor Thomas L. Saaty. The AHP model was established by [16] and has been pragmatic in a diversity of decision-making techniques ranging from simple to complex problems. Particularly, some authors have applied Analytic Hierarchy Process (AHP) to maritime transport studies and this includes; [17] [18] [19] and [20]. [21] suggested that the Analytic Network Process (ANP) can be applied to determine the best city that can be designated as an optimum location for a dry port. Generally, the Analytic Network Process model can be analyzed using the four basic steps below:

- Decision model development and problem structure

- Pairwise comparison matrices and priority vectors

- Super-matrix formation

- Selecting the best alternatives

\subsubsection{Decision Model Development and Problem Structuring}

This is an important part of the whole decision-making process. It marks the beginning of the process and without the correct statement of purpose, the whole decision will be in jeopardy. Therefore, it is imperative that the decision problem is clearly stated and be sectioned accordingly into a rational network. The model can be represented as a directed network, either as a hierarchy or a simple feedback network model. The framework of a particular network is derived through the most suitable technique for the decision which usually requires brainstorming, a survey, or other related forms. Such deliberations provide valuable input in the decision-making practice as structuring the problem allows the decision-maker to ensure a bird's eye view of all issues concerning the complex decision.

\subsubsection{Constructing Pairwise Comparison Matrices and Priority Vectors} Conferring to the AHP, decision variables interacting in the model are compared according to their importance in relation to their criteria. Additionally, the entire clusters are compared pairwisely in regards to their input towards the principal objective of the decision making procedure. Respondents (who are in fact the decision-makers) are asked to perform pairwise evaluations of two variables or clusters in relation to their value to the upper-level criteria. The generic question asked in a pairwise comparison process is that "given a pair of components (elements), how much more does a given member dominate or influence that component with regards to the control element than the other member" [22]. 
Interdependencies among variables in a particular cluster are then examined pairwisely. An eigenvector denotes the influence of each variable on other variables. Saaty's fundamental scale is used to the values employed to denote relative importance among variables as shown in Table 1 below.

From Table 1, a score of 1 denotes two variables which are regarded as of equal importance whereas a score of 9 denotes the great significance of one variable over another. The values of the pairwise comparisons in the AHP are derived conferring to a scale with values which are members of the set: $\{9,8,7,6,5$, $4,3,2,1,1 / 2,1 / 3,1 / 4,1 / 5,1 / 6,1 / 7,1 / 8,1 / 9\}$

Unlike AHP, pairwise comparison in ANP is executed in the framework of a matrix.

The pairwise comparison matrices are in the form presented in Equation (1) below:

$$
A=\left[\begin{array}{ccc}
a_{11} & \cdots & a_{1 n} \\
\vdots & \ddots & \vdots \\
a_{n 1} & \cdots & a_{n n}
\end{array}\right]=\left[\begin{array}{ccc}
w_{1} / w_{1} & \cdots & w_{1} / w_{n} \\
\vdots & \ddots & \vdots \\
w_{n} / w_{1} & \cdots & w_{n} / w_{n}
\end{array}\right]
$$

Matrix $A$ is multiplied by the vector of weights $(w)$, and vector $n \cdot w$ is obtained in Equation (2).

$$
A=\left[\begin{array}{ccc}
w_{1} / w_{1} & \cdots & w_{1} / w_{n} \\
\vdots & \ddots & \vdots \\
w_{n} / w_{1} & \cdots & w_{n} / w_{n}
\end{array}\right] X\left[\begin{array}{c}
w_{1} \\
\vdots \\
w_{n}
\end{array}\right]=n\left[\begin{array}{c}
w_{1} \\
\vdots \\
w_{n}
\end{array}\right]
$$

Re-arranging the formula: $(A-n \cdot 1) \cdot w=0$

The eigenvalue $\lambda_{i}(i=1, \cdots, n)$ are all 0 except 1 . The sum of diagonal equals $n$, if the only $\lambda_{i}$ which is not 0 is $\lambda_{\max }$

Therefore, $\lambda_{i=0}, \lambda_{\max =n}\left(\lambda \neq \lambda_{\max }\right)$

The weighted vector, for $A_{1}, \cdots, A_{n}$ is a standardized eigenvector $\left(\sum w_{i}=1\right)$ for $A$ 's principal eigenvalue, $\lambda_{\max }$

In solving complex problems, we obtain $w^{\prime}$, as $w$ is unknown. $w^{\prime}$ is derived from calculating pair-comparison matrices collated from the respondents. The

Table 1. Fundamental scale of the AHP table.

\begin{tabular}{cc}
\hline Value & Interpretation \\
\hline 1 & Equal importance \\
2 & Weak importance \\
3 & Moderate importance \\
4 & Moderate importance plus \\
5 & Strong importance \\
6 & Strong importance plus \\
7 & Very strong importance \\
8 & Very strong importance plus \\
9 & Extreme importance \\
\hline
\end{tabular}

Data sources: Adapted from Saaty, T.L., 1980, the Analytic Network Process, pg. 3. 
problem then changes to $A^{\prime} \cdot w^{\prime}=\lambda_{\max } \cdot w^{\prime} \quad\left(\lambda_{\max }=\right.$ principal eigenvalue $) \cdot w^{\prime}$ is a normalized eigenvector and $\lambda_{\max }$ which is the principal eigenvalue for $A$ '. In reality, the more complex the circumstances, the more difficult obtaining consistent answers become. As $A^{\prime}$ is not consistent, $\lambda_{\max }$ will always be larger than $n$ (as shown in Equation (3)).

$$
\lambda_{\max }=n+\frac{\sum_{i=1}^{n} \sum_{j=i+1}^{n}\left(w_{j}^{\prime} a_{i j}-w_{i}^{2}\right)^{2}}{w_{i}^{\prime} w_{j}^{\prime} a_{i j}} \cdot n
$$

Consistency of responses can be tested by calculating an appropriate Consistency Index CI shown in Table 2. A perfectly reliable decision maker should obtain $\mathrm{CI}=0$ although small values of discrepancy may be accepted. In general, if the consistency index $(\mathrm{CI})$ is $<0.10$, the consistency of the decision maker is satisfactory.

\subsubsection{Formation of Super-Matrix}

According to [23], global priorities in a framework with interdependencies are obtained when the local priority vectors are inputted in the correct columns of a matrix. The priorities obtained from pairwise comparison matrices in step 2, are inputted as fragments of the columns of a supermatrix. The supermatrix shows the stimulus priority of a variable on the left side of the matrix and a variable at the top of the matrix related to a specific control criterion [24].

Thus, the clusters of a decision framework can be denoted by:

$C_{h}, \quad h=1,2, \cdots, n$, and each cluster $h$ has $n h$ variables, denoted by $C_{h 1}, C_{h 2}, \cdots, C_{h n h}$ as presented in (Equation (4)) below.

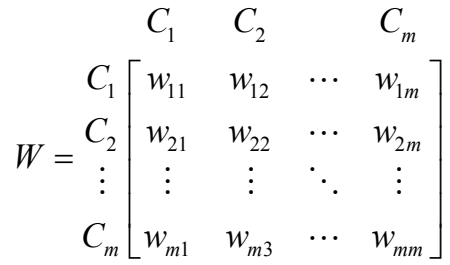

For the ANP, a final comparison matrix from the collection of decision makers is computed from the pairwise comparisons. After the ratio scale priority vectors of the final comparison are sorted out, the vectors are entered in the supermatrix. The geometric mean of elements is used to obtain the final comparison matrices for each decision-maker (Equation (5)).

$$
A_{i j}^{\prime}=\left(\mathrm{II}_{k=1}^{m} A_{I J}^{W K}\right)^{\frac{1}{\sum w k}}
$$

\subsubsection{Selecting the Best Alternative}

The best alternative(s) are selected based on the supermatrix formed in Equation

\begin{tabular}{|c|c|c|c|c|c|c|c|c|c|c|c|c|}
\hline $\mathrm{n}$ & 1 & 2 & 3 & 4 & 5 & 6 & 7 & 8 & 9 & 10 & 11 & 12 \\
\hline $\mathrm{m}$ & 0.00 & 0.00 & 0.58 & 0.90 & 1.12 & 1.24 & 1.32 & 1.41 & 1.45 & 1.49 & 1.51 & 1.53 \\
\hline
\end{tabular}
(4). The final priority weights of every distinct alternative can be established in

Table 2. Random consistency index.

Data sources: Adapted from Saaty, T.L., 1980, the Analytic Network Process, pg. 3. 
the column of alternatives provided as the supermatrix (normalized) covers the entire network. Alternatively, an additional computation must be carried out to obtain the final priorities for alternatives if the supermatrix only covers interrelated clusters. The optimum alternative is identified by the highest overall priority as determined by the matrix operations calculations.

\section{Data and Analysis}

\subsection{Multi-Criteria Evaluation for Dry Port Location Decision Making}

The framework of the ANP network was formed utilizing the Super Decisions software. The structure comprises the main objective or goal at the top, linked to the criteria and sub-criteria. The criteria described above were inputted into the software with the appropriate clusters, sub-clusters and links used to represent the model as accurately as possible. The criteria and sub-criteria were adopted from Samir et al. and modified to suit the research objective in Togo and this is elaborated in Table 3 below.

\subsection{Selecting from Alternatives}

In order to select the best location for the establishment of a dry port in Togo, all the five regions in the country were initially evaluated based on the criteria used in this study (ESF, EF, AF, LF and PF) but only three of them were deemed suitable. Additionally, interviews conducted with group of experts from the Port of Lomé, Ministry of Transport and Shippers from West African Landlocked countries also indicated that these three locations are most appropriate for the establishment of a dry port in Togo and they include; Dapaong (Savannah region), Lomé (Maritime Region) and Sokodé (Central region) (Table 4).

The ANP model includes the variables in the tables above comprising main and sub-criteria that influence the primary goal of choosing an optimum location for a dry port in Togo. The model consists of clusters which include the objective of the decision model, the five defining criteria that influences the decision and their respective sub-criteria represented as nodes, the decision alternatives which consist of the potential dry port locations in Togo. Unlike a typical hierarchical structure, this model includes interdependence between nodes in the main criteria and feedback between alternatives and criteria. An extract of the software is presented in Figure 2 below for a more comprehensive understanding of the ANP model using Super Decision Software.

The model construction serves as the main structure of the decision problem to be evaluated. The model contained one cluster for the objective, one cluster for the main assessment criteria, and one cluster with each for the main criteria containing the sub-criteria linked to the main criteria. The alternatives, which constitute the different potential locations, are also arranged in one cluster. In terms of the network connections, interdependencies are denoted by straight arrows from one cluster to another (depending on direction). After formulating 
Table 3. List of Criteria, sub-criteria and Notations used in the ANP Model.

\begin{tabular}{|c|c|c|c|c|}
\hline Criteria & Sub-Criteria & Code & Sub-Criteria Variable & Code \\
\hline \multirow{6}{*}{$\begin{array}{c}\text { Economic \& } \\
\text { Social Factors } \\
\text { (ESF) }\end{array}$} & Density of Facility Area & DFA & Land Price & LP \\
\hline & \multirow{3}{*}{ Potential Demand Growth } & \multirow{3}{*}{ PDG } & Gross Domestic Product & GDP \\
\hline & & & Employment Rate & ER \\
\hline & & & Industrial Production Index & IPI \\
\hline & \multirow{2}{*}{ Hosting Municipality Range } & \multirow{2}{*}{ HMR } & Population Level & PL \\
\hline & & & Population Density & $\mathrm{PD}$ \\
\hline \multirow{6}{*}{$\begin{array}{c}\text { Environmental } \\
\text { Factors } \\
\text { (EF) }\end{array}$} & \multirow{2}{*}{$\begin{array}{l}\text { Impact on Natural } \\
\text { Environment }\end{array}$} & \multirow[b]{2}{*}{ INE } & Density of Facility Area & DFA \\
\hline & & & $\begin{array}{c}\text { Connectivity to Natural } \\
\text { Environment }\end{array}$ & $\mathrm{CNE}$ \\
\hline & \multirow[b]{2}{*}{ Impact on Urban Areas } & \multirow[b]{2}{*}{ IUA } & Distance to Urban Areas & DUA \\
\hline & & & $\begin{array}{c}\text { Connectivity to Urban } \\
\text { Environment }\end{array}$ & CUE \\
\hline & \multirow{3}{*}{ Hydrology } & \multirow{3}{*}{$\mathrm{H}$} & Flood Level & FL \\
\hline & & & Ground Water Presence & GWP \\
\hline \multirow{13}{*}{$\begin{array}{l}\text { Accessibility } \\
\text { Factors } \\
\text { (AF) }\end{array}$} & & & Number of Railway Accesses & NRA \\
\hline & \multirow[t]{2}{*}{ Accessibility to Rail Network } & \multirow[t]{2}{*}{ ARN } & Demand Gravity & DG \\
\hline & & & Quality of the Rail Network & QRN \\
\hline & \multirow{4}{*}{$\begin{array}{c}\text { Accessibility to High Capacity } \\
\text { Road Network }\end{array}$} & \multirow{4}{*}{$\begin{array}{l}\text { AHCR } \\
\mathrm{N}\end{array}$} & Direct Access to High & \multirow[t]{2}{*}{ DARN } \\
\hline & & & Capacity Network & \\
\hline & & & Distance to the Road Network & DRN \\
\hline & & & Number of Lanes & NL \\
\hline & Accessibility to Sea-ports & ASP & Ports Nearer than $400 \mathrm{~km}$ & $\mathrm{PN}$ \\
\hline & Accessibility to Airports & AA & Distance to an Airport & $\mathrm{DA}$ \\
\hline & \multirow{2}{*}{ Weather } & \multirow{2}{*}{$\mathrm{W}$} & Climatic Variety & $\mathrm{CV}$ \\
\hline & & & Rainfall Level & $\mathrm{RL}$ \\
\hline & \multirow{2}{*}{ Geology } & \multirow{2}{*}{ G } & Excavability & EX \\
\hline & & & Compressive Strength & CS \\
\hline \multirow{6}{*}{$\begin{array}{l}\text { Location } \\
\text { Factors } \\
\text { (LF) }\end{array}$} & \multirow{2}{*}{$\begin{array}{c}\text { Relation with other Logistics } \\
\text { Platforms }\end{array}$} & \multirow{2}{*}{ RLP } & $\begin{array}{l}\text { Number of Nearby } \\
\text { Logistics Platforms }\end{array}$ & NNLP \\
\hline & & & $\begin{array}{l}\text { Belonging to an Industrial } \\
\text { Consolidated Area }\end{array}$ & BICA \\
\hline & $\begin{array}{l}\text { Integration Supply Chain } \\
\text { Infrastructures }\end{array}$ & ISCI & $\begin{array}{l}\text { Distance to a Principal } \\
\text { Freight Corridor }\end{array}$ & DPFC \\
\hline & Potential Optimization & POMS & $\begin{array}{l}\text { Distance to a Principal } \\
\text { Passenger Corridor }\end{array}$ & DPPC \\
\hline & & & Number of Passenger Trips & NPT \\
\hline & Political Stability & PS & Political and Conflict Ledger & PCL \\
\hline $\begin{array}{c}\text { Political } \\
\text { Factors (PF) }\end{array}$ & Administration & A & Taxes, Import \& Export Duties & TIED \\
\hline & Regional Agreements & RA & Transit Trade Agreements & TTA \\
\hline
\end{tabular}

Data sources: Adopted from Samir et al. (2015) [25] and modified by Authors. 
Table 4. Alternatives (Proposed Dry Port Locations).

\begin{tabular}{ccc}
\hline $\begin{array}{c}\text { Maritime Region } \\
\text { (Lomé) }\end{array}$ & $\begin{array}{c}\text { Central Region } \\
\text { (Sokodé) }\end{array}$ & $\begin{array}{c}\text { Sahelian Region } \\
\text { (Dapaong) }\end{array}$ \\
\hline
\end{tabular}

Data sources: Authors, 2018.

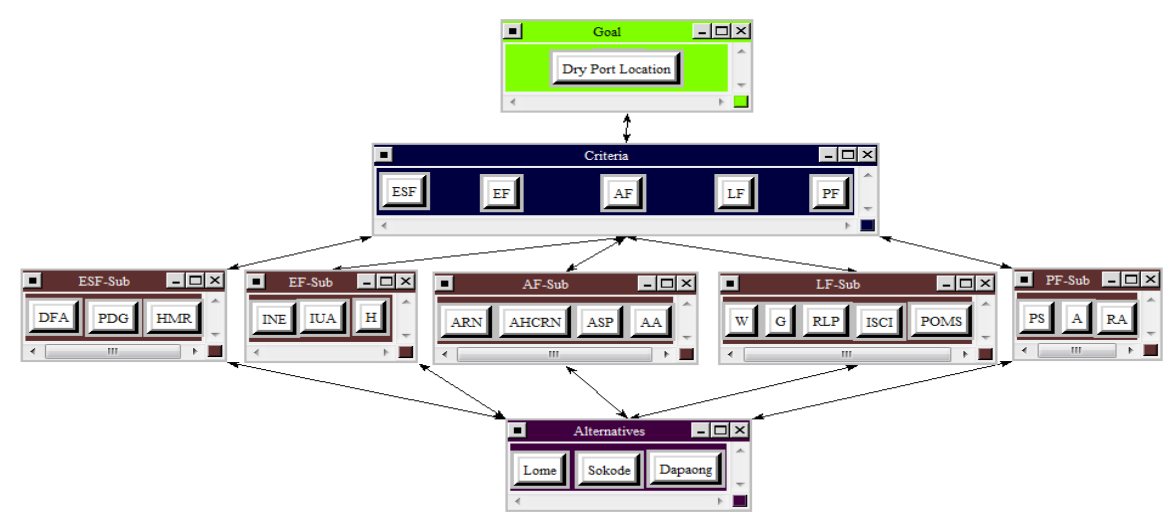

Figure 2. ANP Network of dry port location decision making via Super Decisions. Data source: Authors' extraction from ANP Super Decision Software (2018).

the model, pairwise comparisons between clusters, criteria, sub-criteria and alternatives are initiated with respect to the links provided in the ANP model. This is established to derive the significance of the decision criteria in relation to the overall objective. The weights of criteria were calculated by evaluating each pair of factors by the group of experts knowing that such knowledge is not common to the general public. The values employed in the assessment are specified by numbers ranging from $1-9$, as expressed in Table 1 . The AHP eigenvector technique is used to compute the comparative weights and is a unique way to obtain the ranking or dominance replicated in the pairwise comparison (Table 5) when there is inconsistency in measurement [22].

The numerous questions posed to the decision makers were in form with regards to the goal of selecting an optimum dry port location, what is the comparative importance of Accessibility Factor (AF) to Environmental Factor (EF)? Depending on the scale provided, if the answer is (1/7), the decision maker believes Environmental Factor is very vital relative to Accessibility Factor. Based on the survey and computation of results from the Super Decision software, the criteria used in this study were rated based on the values of the idealized priorities which were converted into three decimal places. Thus, Location Factor LF got the highest rating with a score of (1.000), followed by Economic and Social Factor-ESF (0.888), Accessibility Factor-AF (0.438), Political Factor-PF (0.133) and Environmental Factor-EF (0.089). The inconsistency Ratio was 0.024 which remains insignificant in the pairwise comparison matrices and it also indicates that the results of the study were consistent and reliable.

\subsection{Pairwise Comparison Results of Criteria and Sub Criteria in Dry Port Selection Decision}

The tables representing the pairwise comparison results of the evaluating criteria 
Table 5. Pairwise Comparison and Weights of Major Criteria with respect to goal.

\begin{tabular}{ccccccccc}
\hline & AF & EF & ESF & LF & PF & Normalized & Idealized & Rank \\
\hline AF & 1.000 & 7.000 & 0.500 & 0.333 & 3.000 & 0.172 & 0.438 & 3 \\
EF & 0.143 & 1.000 & 0.125 & 0.125 & 0.500 & 0.035 & 0.089 & 5 \\
ESF & 2.000 & 8.000 & 1.000 & 1.000 & 8.000 & 0.349 & 0.888 & 2 \\
LF & 3.000 & 8.000 & 1.000 & 1.000 & 9.000 & 0.393 & 1.000 & 1 \\
PF & 0.333 & 2.000 & 0.125 & 0.111 & 1.000 & 0.052 & 0.133 & 4 \\
& \multicolumn{7}{c}{ Inconsistency } \\
\hline
\end{tabular}

Data source: Authors' extraction from ANP Super Decision Software (2018).

and sub-criteria with respect to dry port location in Togo can be found in the appendixes. After the development of pairwise comparison matrices, a vector of priorities in each matrix generated is computed and normalized to sum to 1.0 or 100 percent. This is attained by dividing the components of each column of the matrix by the sum of that column (i.e. normalizing the column); after which the Eigenvector is derived by summing the components in each resulting row and dividing this sum by the number of elements in the row so as to obtain the relative weight (Appendix 1). The supermatrix in the ANP model aims to resolve the effects of interdependence that exists between clusters and nodes within clusters of the developed framework. The supermatrix is populated with the weights of interdependence matrices obtained. The column sums of the supermatrix are normalized and will result in a column stochastic matrix. After sub-matrices are inputted into the supermatrix, it is then raised to a large power sufficient enough for convergence to occur (Appendix 2).

\subsection{Ranking Results Regarding the Decision Alternatives}

The objective of this study is to determine an optimum location for the establishment of dry port in Togo. Thus, selecting the best alternative to realize the set objective based on the criteria provided by the researchers. The data was run using the Super Decision software and the synthesize ranking indicates that Sokodé, a city in the central region of Togo is the most preferred location for establishing a dry port in Togo and has an ideal score of (1). Lomé has an ideal score of (0.94) thus ranked second after Sokodé while Dapaong was rated the least location with an ideal score of (0.73). More inclusive information on the ranking result is shown in Table 6 below.

\subsection{Model Sensitivity Analysis}

The sensitivity analysis on the final output from Analytic Network Process is performed using a "what if comparison". This assessment is performed in order to validate that the result of the model is constant regarding the changes in judgments' or variations in inputs. In this study, the sensitivity analysis was directly performed on the five criteria and the three alternatives used in the Super 
Table 6. Synthesized ranking of results with regards to goal.

\begin{tabular}{ccccc}
\hline Name & Ideals & Normal & Raw & Rank \\
\hline Dapaong & 0.733036 & 0.274172 & 0.068543 & 3 \\
Lomé & 0.940603 & 0.351806 & 0.087952 & 2 \\
Sokodé & 1 & 0.374022 & 0.093506 & 1 \\
\hline
\end{tabular}

Data source: Authors' extraction from ANP Super Decision Software (2018).

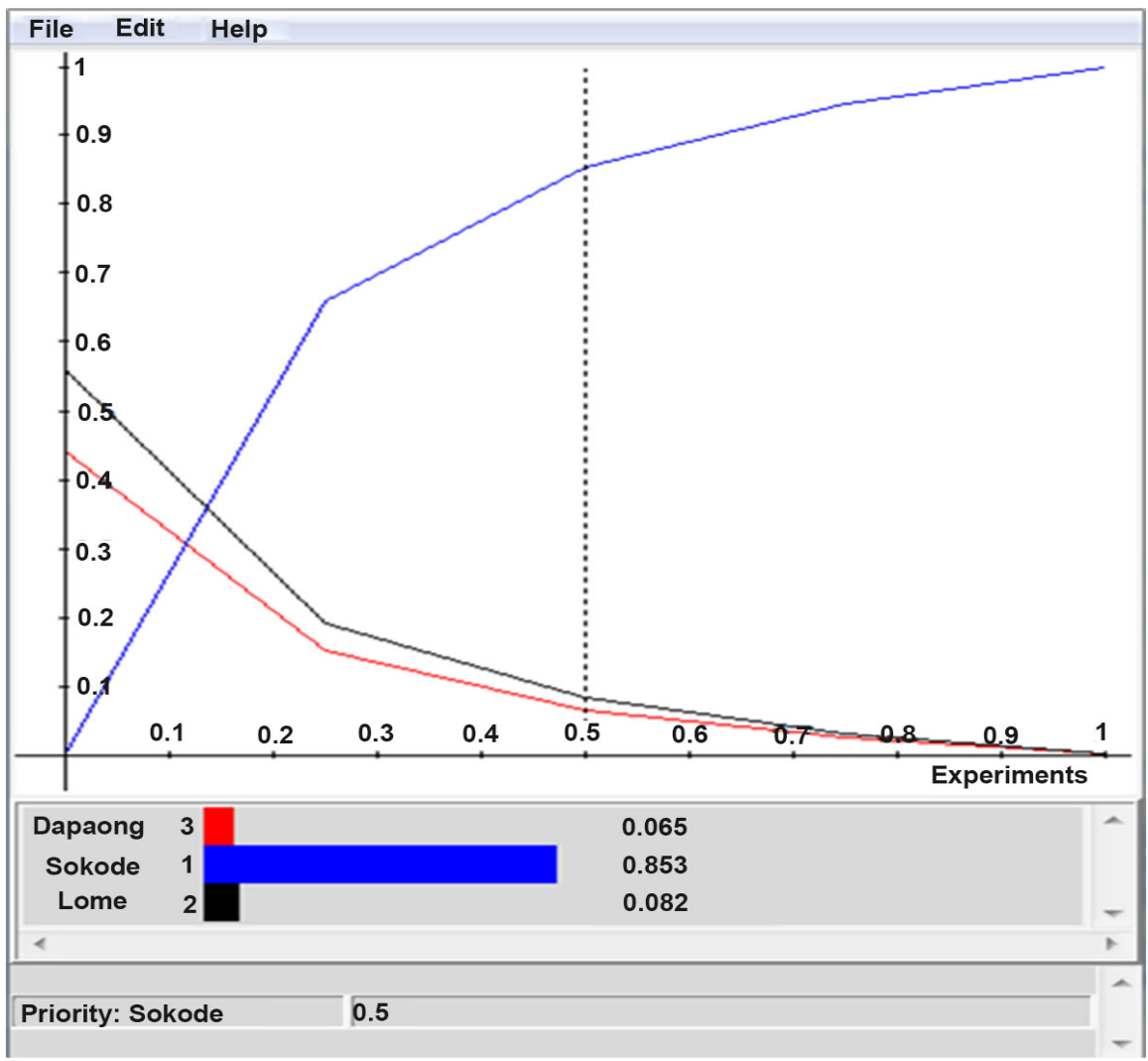

Figure 3. Sensitivity analysis. Source: Researcher's extract from Super Decision software, (2018).

Decision software. A further assessment was conducted on the priorities of alternatives plotted on $\mathrm{Y}$ axis while $\mathrm{X}$ axis denotes the variations in significances of the selected locations. Thus, Figure 3 below extracted from super-decisions software indicates that there is no substantial change to the outcome of the analysis with changes to the inputs variables. From the sensitivity analysis result, Sokodé has the highest score of (0.853) among the selected alternatives while Lomé emerged second with a score of (0.082) and lastly Dapaong with a score of (0.065). Sokodé is located in the central region and it is the second most populated city in Togo aside Lomé. It is also famous for its various commercial activities and serves as a central market along CU9 Lomé-Ouagadougou corridor. In addition to these factors, Sokodé is also known for its outstanding topography and proximity to the current railway network that extends to Blitta in the central region of Togo. 


\section{Conclusion}

The main idea behind this empirical research is to access the establishment of dry port in Togo. This study provides an in-depth Analytic Network Process model as a vital decision-making tool. It also contributes to the existing literatures on dry port development and focuses on the port of Lomé as a gateway port to other West African hinterland nations (Burkina-Faso, Mali \& Niger). In addition to the transshipment function that developing a dry port in Togo could provide, it would also offer services such as customs clearance to shippers in the hinterland markets, consolidation, depot and storage and maintenance of containers. Although the establishment of dry port in Togo would not be a definite solution for the gridlock at the port of Lomé, it would definitely enhance freight transport via Lomé-Ouagadougou CU9 transit Corridor. Aside the generic ecological benefit and the quality of life that Togolese commuters will enjoy when the freight traffic is being shifted from road to rail, the development of dry port at Sokodé would offer the port of Lomé a prospect to increase in its throughput capacity without any physical development at the port and it would also relieve the port of Lomé from challenges regarding environmental issues and insufficient land. And this would in return enhance a supple, steadfast and great capacity flow of transit traffic via Lomé-Ouagadougou CU9 transit corridor.

\section{Acknowledgements}

We would like to extend our sincerest gratitude to all respondents who took part in answering our questionnaire and provided useful suggestions and recommendations during our field study.

\section{Conflicts of Interest}

The authors declare no conflicts of interest regarding the publication of this paper.

\section{References}

[1] Wang, C., Chen, Q. and Huang, R. (2018) Locating Dry Ports on a Network: A Case Study on Tianjin Port. Maritime Policy \& Management, 45, 71-88. https://www.tandfonline.com/doi/abs/10.1080/03088839.2017.1330558?journalCode $=\operatorname{tmpm} 20$ https://doi.org/10.1080/03088839.2017.1330558

[2] Roso, V. (2005) The Dry Port Concept-Applications in Sweden. Proceedings of Logistics Research Network: International Logistics and Supply Chain Management, Plymouth, 7-9 September 2005, 379-382.

[3] Jaržemskis, A. and Vasiliauskas, A.V. (2007) Research on Dry Port Concept as Intermodal Node. Transport, 22, 207-213. https://doi.org/10.3846/16484142.2007.9638126 https://www.tandfonline.com/doi/abs/10.1080/16484142.2007.9638126

[4] Rodrigue, J.-P. and Notteboom, T. (2012) Dry Ports in European and North American Intermodal Rail Systems: Two of a Kind? Research in Transportation Business 
\& Management, 5, 4-15. https://doi.org/10.1016/j.rtbm.2012.10.003 http://www.sciencedirect.com/science/article/pii/S2210539512000673

[5] Mwemezi, J.J. and Huang, Y.F. (2012) Inland Container Depot Integration into Logistics Networks Based on Network Flow Model: The Tanzanian Perspective. African Journal of Business Management, 6, 7149-7157. https://doi.org/10.5897/AJBM12.294

[6] Rutten, B.C.M. (1998) The Design of a Terminal Network for Intermodal Transport. Transport Logistics, 1, 279-298. https://doi.org/10.1163/156857098300155278

[7] Rosso, V., Woxenius, J. and Olandersson, G. (2006) Organization of Swedish Dry Ports.

https://www.gu.se/digitalAssets/1344/1344736_2006_meddelande_123_-_sustaccess \%20_dry_ports_in_sweden.pdf

[8] Roso, V. and Lumsden, K. (2010) A Review of Dry Ports. Maritime Economics \& Logistics, 12, 196-213. https://link.springer.com/article/10.1057/mel.2010.5 https://doi.org/10.1057/mel.2010.5

[9] Nguyen, C.L. and Notteboom, T. (2016) Dry Ports as Extensions of Maritime Deep-Sea Ports: A Case Study of Vietnam. https://doi.org/10.24006/jilt.2016.14.1.003 https://biblio.ugent.be/publication/8042448/file/8042449.pdf

[10] Augustin, D.S. and Akossiwa, D.L. (2018) SWOT Analysis for Developing Dry Ports in Togo. American Journal of Industrial and Business Management, 8, 1407-1417. https://doi.org/10.4236/ajibm.2018.86094

[11] Degbe, S.A. and Song, B. (2019) Dry Ports Development: A Pivot Strategy to Enhance Sustainable Transit Traffic via West African Corridors. Athens ATINER's Conference Paper Series, No. TRA2018-2630. http://www.atiner.gr/papers/TRA2018-2630.pdf

[12] Roso, V., Woxenius, J. and Lumsden, K. (2009) The Dry Port Concept: Connecting Container Seaports with the Hinterland. Journal of Transport Geography, 17, 338-345. https://doi.org/10.1016/j.jtrangeo.2008.10.008

[13] Beresford, A., Pettit, S., Xu, Q. and Williams, S. (2012) A Study of Dry Port Development in China. Maritime Economics \& Logistics, 14, 73-98. https://doi.org/10.1057/mel.2011.17

[14] Liu, Q. and Cai, Y.F. (2009) Study of Linkage Development between Dry Port and Sea Port. Port Economy, 9, 24-26. (In Chinese)

[15] Tarcan, H. (2011) Analysis of Possibilities the North Aegean Candarli Port of Being a Regional Hub Port in the Mediterranean Sea Region. All Dissertations, Paper 134, World Maritime University, Malmö.

[16] Saaty, T.L. (1980) The Analytic Hierarchy Process. McGraw-Hill, New York.

[17] Ugboma, C., Ugboma, O. and Ogwude, I. (2006) An Analytical Hierarchy Process (AHP) Approach to Port Selection Decisions-Empirical Evidence from Nigerian Ports. Maritime Economics and Logistics, 8, 251-266. https://doi.org/10.1057/palgrave.mel.9100160

[18] Lirn, T.-C., Thanopoulou, H., Beynon, M. and Beresford, A. (2004) An Application of AHP on Transhipment Port Selection: A Global Perspective. Maritime Economics and Logistics, 6, 70-91. https://doi.org/10.1057/palgrave.mel.9100093

[19] Song, D.-W. and Yeo, K.-T. (2004) A Competitive Analysis of Chinese Container Ports Using the Analytic Hierarchy Process. Maritime Economics and Logistics, 6, 34-52. https://doi.org/10.1057/palgrave.mel.9100096

[20] Guy, E. and Urli, B. (2006) Port Selection and Multi-Criteria Analysis: An Applica- 
tion to the Montreal-New York Alternative. Maritime Economics and Logistics, 8, 169-186. https://doi.org/10.1057/palgrave.mel.9100152

[21] Wang, C.-H. and Wei, J.-Y. (2008) Research on the Dry Port Location of Tianjin Port Based on Analytical Network Process. 2008 International Seminar on Business and Information Management, Wuhan, 19 December 2008, 75-78. http://ieeexplore.ieee.org/stamp/stamp.jsp?arnumber=05117434

[22] Kong, F. and Liu, H.-Y. (2007) Evaluation of Logistics Service Provider Using Analytic Network Process. Natural Computation: Third International Conference on Natural Computation, Haikou, 24-27 August 2007, Vol. 2, 227-231.

[23] Yüksela, İ. and Devirenb, M.D. (2007) Using the Analytic Network Process (ANP) in a SWOT Analysis: A Case Study for a Textile Firm. Information Sciences, 177, 3364-3382. https://doi.org/10.1016/j.ins.2007.01.001

[24] Saaty, T. (1996) Decision Making with Dependence and Feedback: The Analytic Network Process. RWS Publications, Pittsburgh.

[25] Awad-Núñez, S., González-Cancelas, N., Soler-Flores, F. and Camarero-Orive, A. (2015) How Should the Sustainability of the Location of Dry Ports Be Measured? A Proposed Methodology Using Bayesian Networks and Multi-Criteria Decision Analysis. Transport, 30, 312-319. https://doi.org/10.3846/16484142.2015.1081618 


\section{Appendix 1}

Table A1. Relative weights of Accessibility factors sub-criteria.

\begin{tabular}{ccccccc}
\hline & AA & AHCRN & ARN & ASP & Normalized & Idealized \\
\hline AA & 1.000 & 0.250 & 0.500 & 0.200 & 0.084 & 0.183 \\
AHCRN & 4.000 & 1.000 & 3.000 & 2.000 & 0.460 & 1.000 \\
ARN & 2.000 & 0.333 & 1.000 & 1.000 & 0.188 & 0.410 \\
ASP & 5.000 & 0.500 & 1.000 & 1.000 & 0.268 & 0.583 \\
& \multicolumn{7}{c}{ Inconsistency } & & 0.0477 \\
\hline
\end{tabular}

Data source: Authors' extraction from ANP Super Decision Software (2018).

Table A2. Relative weights of Environmental factors sub-criteria.

\begin{tabular}{cccccc}
\hline & $\mathrm{H}$ & INE & IUA & Normalized & Idealized \\
\hline $\mathrm{H}$ & 1.000 & 0.333 & 0.250 & 0.122 & 0.218 \\
$\mathrm{INE}$ & 3.000 & 1.000 & 0.500 & 0.320 & 0.572 \\
$\mathrm{IUA}$ & 4.000 & 2.000 & 1.000 & 0.558 & 1.000 \\
& & Inconsistency & & & 0.0176
\end{tabular}

Data source: Authors' extraction from ANP Super Decision Software (2018).

Table A3. Relative weights of Economic \& Social factors sub-criteria.

\begin{tabular}{cccccc}
\hline & DFA & HMR & PDG & Normalized & Idealized \\
\hline DFA & 1.000 & 0.250 & 0.167 & 0.089 & 0.151 \\
HMR & 4.000 & 1.000 & 0.500 & 0.323 & 0.550 \\
PDG & 6.000 & 2.000 & 1.000 & 0.588 & 1.000 \\
& & Inconsistency & & 0.0089 \\
\hline
\end{tabular}

Data source: Authors' extraction from ANP Super Decision Software (2018).

Table A4. Relative weights of Location factors sub-criteria.

\begin{tabular}{cccccccc}
\hline & G & ISCI & POMS & RLP & W & Normalized & Idealized \\
\hline G & 1.000 & 0.333 & 0.250 & 0.200 & 4.000 & 0.089 & 0.270 \\
ISCI & 3.000 & 1.000 & 1.000 & 0.500 & 6.000 & 0.230 & 0.702 \\
POMS & 4.000 & 1.000 & 1.000 & 2.000 & 5.000 & 0.328 & 1.000 \\
RLP & 5.000 & 2.000 & 0.500 & 1.000 & 7.000 & 0.313 & 0.955 \\
W & 0.250 & 0.167 & 0.200 & 0.143 & 1.000 & 0.040 & 0.121 \\
& & & Inconsistency & & & 0.0662 \\
\hline
\end{tabular}

Data source: Authors' extraction from ANP Super Decision Software (2018).

Table A5. Relative weights of Political factors sub-criteria.

\begin{tabular}{cccccc}
\hline & A & PS & RA & Normalized & Idealized \\
\hline A & 1.000 & 0.333 & 2.000 & 0.238 & 0.382 \\
PS & 3.000 & 1.000 & 4.000 & 0.625 & 1.000 \\
RA & 0.500 & 0.250 & 1.000 & 0.136 & 0.218 \\
& & Inconsistency & & & 0.0176
\end{tabular}

Data source: Authors' extraction from ANP Super Decision Software (2018). 


\section{Appendix 2}

Table A6. Priorities of dry port selection decision alternatives.

\begin{tabular}{|c|c|c|}
\hline Name & Normalized By Cluster & Limiting \\
\hline Goal & 1 & 0.041667 \\
\hline Dapaong & 0.27521 & 0.068803 \\
\hline Sokodé & 0.37466 & 0.093666 \\
\hline Lomé & 0.35013 & 0.087532 \\
\hline $\mathrm{AF}$ & 0.19233 & 0.056097 \\
\hline $\mathrm{EF}$ & 0.16181 & 0.047194 \\
\hline ESF & 0.25611 & 0.074698 \\
\hline $\mathrm{LF}$ & 0.22277 & 0.064976 \\
\hline PF & 0.16698 & 0.048702 \\
\hline AA & 0.23403 & 0.019503 \\
\hline AHCRN & 0.27015 & 0.022513 \\
\hline ARN & 0.24408 & 0.02034 \\
\hline ASP & 0.25173 & 0.020978 \\
\hline $\mathrm{H}$ & 0.31624 & 0.026353 \\
\hline INE & 0.33222 & 0.027685 \\
\hline IUA & 0.35154 & 0.029295 \\
\hline DFA & 0.30204 & 0.02517 \\
\hline HMR & 0.33207 & 0.027672 \\
\hline PDG & 0.36589 & 0.030491 \\
\hline G & 0.18759 & 0.015632 \\
\hline ISCI & 0.20337 & 0.016947 \\
\hline POMS & 0.21428 & 0.017856 \\
\hline RLP & 0.21262 & 0.017718 \\
\hline $\mathrm{W}$ & 0.18215 & 0.015179 \\
\hline A & 0.33333 & 0.027778 \\
\hline PS & 0.33333 & 0.027778 \\
\hline RA & 0.33333 & 0.027778 \\
\hline
\end{tabular}

Data source: Authors' extraction from ANP Super Decision Software (2018). 